\title{
LETTER
}

\section{Mind the influence of arterial oxygen tension on central venous oxygen saturation}

\author{
Huai-wu He, Da-wei Liu*, Yun Long and Xiao-ting Wang \\ See related research by Hernandez et al., http://ccforum.com/content/13/3/R63
}

We read with great interest the study by Hernandez and colleagues published in Critical Care [1]. The study showed that central venous oxygen saturation $\left(\mathrm{ScvO}_{2}\right)$ increased significantly in response to emergency intubation, and the authors suggested that the early normalization of $\mathrm{ScvO}_{2}$ after intubation might not be reliable to reflect successful resuscitation. However, they might have ignored the influence of arterial oxygen tension $\left(\mathrm{PaO}_{2}\right)$ on $\mathrm{ScrO}_{2}$.

It is well known that when arterial oxygen saturation is approaching $100 \%$, the increase in oxygen delivery would be limited in response to the increase of $\mathrm{PaO}_{2}$. However, a very high $\mathrm{PaO}_{2}$ could significantly influence $\mathrm{ScvO}_{2}$ even if arterial oxygen saturation reaches $100 \%$. Pre-oxygenation may result in a very high $\mathrm{PaO}_{2}$ in the emergency intubation, so $\mathrm{PaO}_{2}$ should be taken as a potentially confounding factor. Very high $\mathrm{PaO}_{2}$ (about $288 \mathrm{mmHg}$ ) has a more significant and consistent effect on $\mathrm{ScvO}_{2}$ than a relevant change in cardiac index $(>10 \%)$ [2]. Moreover, a decrease in the whole body oxygen consumption under hyperoxia has been reported in critically ill patients [3], and animal studies also noted that hyperoxia could result in the redistribution of cardiac output [4]. Recently, Legrand and colleagues documented that an increase in $\mathrm{PaO}_{2}$ could increase $\mathrm{ScvO}_{2}$ without increasing oxygen delivery [5].

It is worth paying attention to the impact of $\mathrm{PaO}_{2}$ on $\mathrm{ScvO}_{2}$ in the management of critically ill patients.

Abbreviations

$\mathrm{PaO}_{2}$ : Arterial oxygen tension; $\mathrm{ScrO}_{2}$ : Central venous oxygen saturation.

\section{Competing interests}

The authors declare that they have no competing interests.

\section{References}

1. Hernandez G, Peña H, Cornejo R, Rovegno M, Retamal J, Navarro J, Aranguiz I, Castro R, Bruhn A: Impact of emergency intubation on central venous oxygen saturation in critically ill patients: a multicenter observational study. Crit Care 2009, 13:R63.

2. Ho KM, Harding R, Chamberlain J: The impact of arterial oxygen tension on venous oxygen saturation in circulatory failure. Shock 2008, 29:3-6.

3. Reinhart K, Bloos F, Konig F, Bredle D, Hannemann L: Reversible decrease of oxygen consumption by hyperoxia. Chest 1991, 99:690-694.

4. Barth E, Bassi G, Maybauer DM, Simon F, Gröger M, Oter S, Speit G, Nguyen CD, Hasel C, Möller P, Wachter U, Vogt JA, Matejovic M, Radermacher P, Calzia E: Effects of ventilation with $100 \%$ oxygen during early hyperdynamic porcine fecal peritonitis. Crit Care Med 2008, 36:495-503.

5. Legrand M, Vallée F, Mateo J, Payen D: Influence of arterial dissolved oxygen level on venous oxygen saturation: don't forget the PaO2! Shock 2014, 41:510-513.

\section{doi:10.1186/s13054-014-0569-y}

Cite this article as: He et al:: Mind the influence of arterial oxygen tension on central venous oxygen saturation. Critical Care 2014 18:569.

Published online: 16 October 2014

\footnotetext{
*Correspondence: tjmuhhw@163.com

Department of Critical Care Medicine, Peking Union Medical College

Hospital, Chinese Academy of Medical Sciences, 1 shuaifuyuan, Dongcheng

District, Beijing 100730, China
}

\section{Biomed Central}

(c) 2014 He et al.; licensee BioMed Central Ltd. This is an Open Access article distributed under the terms of the Creative Commons Attribution License (http://creativecommons.org/licenses/by/4.0), which permits unrestricted use, distribution, and reproduction in any medium, provided the original work is properly credited. The Creative Commons Public Domain Dedication waiver (http://creativecommons.org/publicdomain/zero/1.0/) applies to the data made available in this article, unless otherwise stated. 